\title{
INTRODUCTION OF LUCERNE INTO ACID SOILS
}

\author{
J. G. H. WHITE
}

Senior Lecturer in Plant Science, Lincoln College

IT Is wELI kNown that the key to pasture improvement in the tussock country of the South Island is in the introduction of high-producing legumes. White, red and alsike clovers have been widely used with considerable success. Lucerne, as yet, is much less important, even though it has been shown by Iversen ( 196.5) that on droughty soils it can produce much more dry matter than conventional pastures. One of the main reasons for the lesser use of lucerne is the difficulty in establishing the plant by surface sowing methods, particularly in acid soils. On the high $\mathrm{pH}$ brown-grey earths of Central Otago, lucerne can be sod-seeded into scabweed country quite successfully (Ludecke, 1962) and large areas have been sown by this means. On the more acid yellow-grey and yellow-brown earths, however, with denser plant cover, lucerne is commonly established only by conventional methods of cultivation and broadcast liming, even though there is considerable scope for its extended introduction into droughty situations by cheaper means.

Lucerne is particularly sensitive to acid soil conditions which affect establishment and growth in several ways. Lucerne rhizobia (Rhizobium meliloti) are much less tolerant of acid soils than clover rhizobia (R. trifolii) and are absent from most soils in New Zealand (Greenwood, 1964). Clover rhizobia can tolerate soil pH levels of 5.5 or even less, but lucerne rhizobia prefer $\mathrm{pH}$ levels of 6.0 higher and nodulation failures are common if the soil $\mathrm{pH}$ is much below this.

Calcium is essential for nodulation of most legumes and is required in greater amounts by lucerne than by many other legumes (J. G. H. White and J. K. Powrie, unpubl. data). In acid soils, this element may be absent or reduced in availability owing to effects of high levels of manganese, aluminium or hydrogen ions. Acid soils are also known to affect normal taproot development in lucerne, and 
taproots may become forked and grow sideways on meeting an acid subsoil (Schmehl et al., 1952; J. G. H. White and J. K. Powrie, unpubl. data).

There are two possible approaches to overcoming problems of establishing lucerne on acid soils. The usual method is to modify the soil environment to suit the plant, by heavy broadcast liming. This is often uneconomic in tussock country owing to high transport costs. A nother approach is to select strains of $R$. meliloti and species of lucerne which are more tolerant of acid soils. The latter approach has distinct possibilities, but, at present, it is a relatively new field.

At Lincoln College an attempt is being made to combine both approaches in overcoming establishment problems in the tussock country. Acid tolerant species of lucerne and strains of lucerne rhizobia are being sought, and the use of limited quantities of lime, either pelleted on the seed or sown in the drill row, is being investigated. In addition, methods of surface introduction and time of sowing are being examined, as they have an important bearing on the successful establishment of lucerne in tussock country, but little information is yet available. So far most of the trial work conducted by the Plant Science Department has been on Mesopotamia Station, in the upper Rangitata Valley of South Canterbury, and this paper reports on some of the findings to date. Field trials were sited on a terrace typical of several thousands of acres in the vicinity, and covered in fescue tussock, browntop and sweet vernal. The mean annual rainfall is 38 in. The soil is classified as an upland yellow-brown earth, Mesopotamia series, and is deficient in both phosphorus and sulphur and probably also in molybdenum. The $\mathrm{pH}$ of the topsoil is 5.5 and there is little change down the profile.

Seed Pelleting Trials

It is now well known that coating of inoculated legume seed with certain materials may assist in nodulation, particularly on acid soils, and pelleting of lucerne seed may be $a$ means of reducing the need for heavy liming. A pot trial, using Mesopotamia soil, was conducted in a glasshouse in the winter of 1965 to compare the effects of three pelleting treatments on nodulation in the presence or absence of lime applied at the rate of 1 ton per acre. 
TABLE 1: EFFECTS OF LIME AND SEED PELLETING ON NODULATION

\begin{tabular}{|c|c|c|}
\hline \multicolumn{2}{|l|}{ Treatment } & $\%$ Nodulation \\
\hline Unpelleted & $\ldots$ & $\ldots 6.1$ \\
\hline Phosphate/dolomite pellet & $\ldots$ & . . . 21.8 \\
\hline Lime pellet & & $\ldots 90.9$ \\
\hline Unpelleted plus 1 ton & e/acre $\quad \ldots$ & $\ldots 90.6$ \\
\hline Phosphate/dolomite pellet $\mathrm{p}$ & 1 ton lime/acre & $\ldots 89.8$ \\
\hline Lime pellet plus 1 ton lin & & $\ldots .92 .7$ \\
\hline
\end{tabular}

The trial was of factorial design and was replicated four times.

Table 1 shows that, in the absence of lime, nodulation was very poor where no pellet was applied, and that the lime pellet was markedly superior to the Nauru phosphate/ dolomite pellet. In the presence of lime, no response to pelleting occurred, but lime pelleting resulted in nodulation equal to that obtained from heavy liming.

A field trial comparing pellets of lime, Gafsa phosphate and dolomite, alone or in combination, was sown at Mesopotamia on September 28, 1965. Each treatment was replicated five times. A basal dressing of 4 cwt of superphosphate and $2 \mathrm{oz}$ of sodium molybdate per acre was applied to all plots following burning of tussock and browntop. Certified New Zealand Wairau lucerne, at $15 \mathrm{lb}$ per acre, was broadcast on one half of each plot and sown in drill rows on the other half. The drilled seed was hand sown in grooves made by tines of a Gravelly tractor, to simulate sod-seeding. N odules were visible on some plants 7 weeks from sowing, and after 11 weeks 20 plants were harvested at random from the drilled area and assessed for nodulation. In the broadcast area all plants were harvested within a 5-inch ring, thrown five times at random, and similar measurements made.

Table 2 shows the results from the drilled plots. Lime was again the best pelleting material, and any mixtures containing lime were superior to Gafsa phosphate/ dolomite or dolomite alone. Gafsa phosphate alone did not form a stable pellet and was not included in the treatments. In the absence of seed pelleting no plants became nodulated. 
TABLE 2: EFFECTS OF PELLETING ON NODULATION (Drilled Area)

\begin{tabular}{|c|c|c|c|}
\hline Pelleting Treatment & & & $\%$ Nodulation \\
\hline Lime alone .... $\quad \ldots$ & .... & .... & $\ldots 60.4$ \\
\hline Lime/Gafsa phosphate & $\ldots$ & & $\ldots 48.2$ \\
\hline Lime/dolomite & & $\ldots$. & $\ldots 37.4$ \\
\hline Dolomite $\quad \ldots \quad \ldots$ & $\ldots$ & $\ldots$. & $\ldots 34.4$ \\
\hline Gafsa phosphate/dolomite & & $\ldots$ & $\ldots \quad 21.6$ \\
\hline Inoculated seed & & & $\ldots 0.8$ \\
\hline Uninoculated seed .... & $\ldots$ & $\ldots$ & .... Nil \\
\hline
\end{tabular}

TABLE 3: EFFECT OF METHOD OF SOWING ON NODULATION (Mean of all pelleting treatments)

\begin{tabular}{llllc}
\hline & & $\%$ & Nodulation & Nodules/plant \\
\hline Drilled & $\ldots$ & $\ldots$ & $\ldots, 44$ & 2.2 \\
Broadcast & $\ldots$. & & $\ldots \ldots 20$ & 1.4 \\
\hline
\end{tabular}

TABLE 4: EFFECT OF TIME OF SOWING ON PERCENTAGE NODULATION

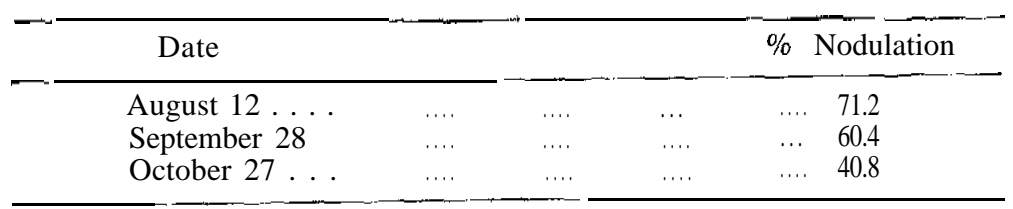

Method OF SOWING

Drilled or "sod-seeded" plots were superior to broadcast plots in all pelleting treatments. Table 3 summarizes the results. N ot only was the percentage of nodulated plants much higher where seed was drilled, but more nodules were present on the nodulated plants suggesting greater rhizobial survival and higher numbers present during nodulation.

Time OF Sowing

To obtain information on the optimum sowing date for lucerne at Mesopotamia, a trial was laid down comparing sowings of lime-pelleted seed in August, September and October. Table 4 shows the effect of time of sowing on percentage noduiation of plants sown in drill rows. 
TABLE 5: INTERACTION OF LIME PELLETING AND LIMING ON ESTABLISHMEN?

(Means of a O-5 score for vigour and density, 5 months from sowing)

\begin{tabular}{|c|c|c|}
\hline & No Pellet & Lime Pellet \\
\hline No Lime & 0.25 & 1.38 \\
\hline $1 \frac{1}{2}$ tons lime per acre .... & . . 2.54 & 2.80 \\
\hline 3 tons lime per acre $\ldots$ & $\ldots 3.50$ & 3.40 \\
\hline
\end{tabular}

It would appear that late August or early September is likely to be the best time to sod-seed at Mesopotamia. Drier conditions with strong north-west winds occur from October onwards and nodulation is likely to be adversely affected

\section{Iime Pelieting-Liming Interaction}

In September 1965, a trial was sod-seeded with a farm drill to examine interactions between lime pelleting and liming on lucerne nodulation and growth. Lime-pelleted and unpelleted seed of College Glutinosa lucerne was compared in factorial combination with three levels of liming $\left(0,1 \frac{1}{2}\right.$, and 3 tons per acre) and two cultivation treatments (no cultivation, and surface working). Initial establishment was good in all plots which either received lime or were sown with lime-pelleted seed but Table 5 shows that after 5 months those plots receiving lime were considerably better than those which were sown with lime pelleted seed in the absence of lime. These differences still persist.

\section{RHIZOBIUM NUMBeR}

Work in Australia (J. G. H. White and J. K. Powrie, unpubl. data) has shown that in acid soils nodulation of lucerne may be improved by increasing rhizobium number on the inoculated seed. Two levels of inoculum were therefore used in sowings of lime-pelleted seed at Mesopotamia, in August, September and October. Although no response to the heavier rate of inoculum was obtained from the August and September sowings, the increases in nodulation obtained in the October sowing (Table 6) would suggest that inoculum level is a factor worthy of further study. 
TABLE 6: EFFECT OF RHIZOBIUM NUMBER ON NODLJLATION

(October sowing-drill row)

\begin{tabular}{lrcrc}
\hline & \multicolumn{2}{c}{ Rhizobia/Seed } & \multicolumn{2}{c}{ Nodulation } \\
& & At sowing & After 45 days & $\%$ \\
\hline Inoculation only & $\ldots . .$. & 1650 & 300 & Nil \\
Inoculation and lime pellet & $\ldots$ & 1650 & 1200 & 40.8 \\
Triple inoculation and lime pellet & 9400 & 6500 & 54.2 \\
\hline
\end{tabular}

High numbers of cells were still present on triple inoculated seed stored for $\mathbf{4 5}$ days, but numbers were low on unpelleted normally inoculated seed.

\section{Discussion}

The results of the pelleting trials strongly suggest that in moderately acid soils, effective nodulation of lucerne can be obtained by pelleting of inoculated seed, and that fine lime is the best material to use. The reasons for the beneficial effects of lime are not fully resolved but are probably three-fold.

(1) Raising the $\mathrm{pH}$ of the soil immediately adjacent to the seed, thus permitting better survival and/ or multiplication of the rhizobia.

(2) Providing calcium for nodulation. Calcium is required in greater amounts for nodulation than for plant growth and may be reduced in availability in some acid soils.

(3) Protecting rhizobia from desiccation.

Rhizobia on surface-sown seed may die rapidly if dry conditions follow sowing, unless protected from sun and wind by a coating material.

The highly significant improvement in nodulation of lucerne where lime-pelleted seed was used is in marked contrast to results obtained by Adams (1964) and Cullen and Ludecke (1966) with lime-pelleted clover seed, where depressions in nodulation and/ or plant growth were obtained. It is obvious that effects of pelleting on nodulation of legumes growing in acid soils are complex, and that R. meliloti is affected quite differently from $\mathbf{R}$. trifolii.

In nutrient solutions, Jensen (1942) found that R . trifolii failed to grow at $\mathrm{pH} 7.1$ to 7.5 and that it had an optimum 
at pH 5.5 to 6.5 , whereas $R$. meliloti had an optimum at $\mathrm{pH} 7$ to 8 and could grow above $\mathrm{pH}$ levels of 8.7. The high $\mathrm{pH}$ conditions which exist within the lime pellet may therefore be deleterious to the strains of $R$. trifolii at present being used in inoculant cultures in $\mathrm{New}$ Zealand. It is significant that no record of depressions due to lime pelleting of clover have yet been reported from Australia, where pelleted seed is widely used but with different strains of $R$. trifolii.

Although lime pelleting can produce a high percentage of nodulated lucerne in moderately acid soils, it may not necessarily result in optimum lucerne growth, as the results from the trial comparing lime pelleting and liming would indicate. Here, the growth of lucerne in limed plots was much better than where lime-pelleted seed was sown without lime. This aspect is being followed up this year and a field trial with four rates of liming was sown in August. Three lucerne species are also included in this trial to find out if there are differences in their tolerance of acid soil conditions. No work is at present being carried out on acid-tolerant strains of $R$. meliloti, but the Microbiology Department at Lincoln College is interested in this aspect, and it may prove a fruitful line of research.

The results from trials on time and method of sowing indicate that sod-seeding in late A ugust or early September - will give best results. This confirms the results of trials in Central Otago where early autumn or early spring were found to be the best times for sod-seeding of lucerne (Ludecke, 1962). Although broadcasting gave much poorer nodulation than sod-seeding it should not be dismissed completely as a method of introducing lucerne. It is much faster than sod-seeding and of course can be used on hillcountry too steep for machinery. Preliminary trials with broadcasting of creeping lucerne are being conducted on "Hunua", the College hill-country property in North Canterbury. The trial is on a steep, sunny slope covered in danthonia, and paraquat is being used to reduce the dense cover. The soil is a yellow-grey earth, Haldon series, with a $\mathrm{pH}$ of 6.0 .

The Plant Science Department at Lincoln College is developing two creeping lucernes which could have an important place in tussock grasslands. College Glutinosa, an improved rhizomatous creeper selected 
from Glutinosa is at present under test at a number of sites in the tussock country and results of its performance should be known in a year or two. Seed of a creeping rooted lucerne, the result of a cross between Glutinosa and Rambler is likely to be available for trial work in 1967. It is hoped that these new varieties, combined with the results of work on establishment problems, will encourage farmers to extend their lucerne sowings on many tussock properties.

\section{REFERENCES}

Adams, A. F. R., 1964: Proc. 26th Conf. N.Z. Grassl. A ss.: 115-22.

Cullen, N. A.; Ludecke, T. E., 1966: Proc. 28th Conf. N.Z. Grussl. Ass.: 96-104.

Greenwood, R. M., 1964: Proc. 26th Conf. N.Z. Grassl. Ass.:95-101. Iversen, E., 1965: Proc. 15th Lincoln Coll Finrs.' Cont, : 78-83.

Jensen, H. L., 1942: Proc. Linn. Soc. N.S.W. 67:98-108.

Ludecke, T. E., 1962: N.Z. J. Agric., 104:168-75.

Schmehl, W. R.; Peech, M.; Bradfield, R., 1952: Soil Sci., 73, 11-21.

\section{DISCUSSION}

What is the maintenance dressing of lime required to keep lucerne growing on this country?

We have not investigated this aspect yet, but if we can develop acidtolerant lucerne and medic bacteria, the requirement may bc quite low.

A re there any differences in limes used for pelleting, and if so, are they likely to have different effects?

From work carried out in Oregon, U.S.A., it seems likely that some limes give better nodulation than others. Finely-ground lime is essential, whatever the source.

Is it worth while sowing lucerne on soils with acid subsoils?

Whcre stands are being established by conventional means, it is essential to plough lime down twelve months before sowing. Where overdrilling is being carried out. however, it may be possible to establish lucerne by using acid-tolerant strains, lime-pelleted seed, and fine lime in the drill row. We are currently looking at these aspects at Mesopotamia.

$\mathrm{H}$ ave you investigated aerial application of lucerne seed?

No, but the broadcast plots will provide some guide as to its success. 


\section{LUCERNE ON ACID SOILS}

Are these problem soils in the minority? Are there any soils where legumes can be established without much difficulty?

The situation with lucerne is quite different from that with clovers. With clovers, the problem soils are certainly in the minority and as far as we know are confined to the more acid yellow-brown earths, and certain semi-arid danthonia-dominant country such as the Wither Hills. Elsewhere clovers can be established easily by topdressing and sowing inoculated seed at the correct time. Lucerne, because it is much less acid tolerant, is difficult to establish on all soils except the brown-grey earths unless practices such as liming are carried out. 